COMMENT

https://doi.org/10.1057/s41599-019-0250-9

\title{
OPEN
}

\section{What leisure? Surfeminism in an era of Trump}

\author{
Krista Comer ${ }^{1}$
}

\begin{abstract}
Powerful new feminisms are challenging the rise of the Global Right through mass mobilization, demands for accountability, and innovative opposition, such as \#MeToo, the Global Women's Marches, and \#Feminism4the99. The international forum Signs: A Journal of Women and Culture has urged feminist scholars to meet the moment by bridging academic and larger feminist publics and attending to creative, new feminist movements. This paper showcases one such example, surfeminism, a theory and action project working between publics of academia and global surfing. Surfeminism is a worldwide network connecting people, ideas, particular coastal geographies, online and real-time communities and microeconomies in surf industry, with activisms focused on protests of sexism in surf media, access to ocean spaces, environmental health, and women's racial, economic, and reproductive justice. The paper lays out surfeminist publics through discussion of the Institute for Women Surfers (IWS), a public humanities project in grassroots political education emphasizing relationships, cross-geography alliances, and critical thought. One of the more important and complex claims of surfeminism is for women and girls' leisure as a feminist political need. A discussion of leisure and its relation to authoritarianisms, as well as ideologies of so-called postfeminism closes the paper.
\end{abstract}

\footnotetext{
${ }^{1}$ Rice University, Houston, TX, USA. Correspondence and requests for materials should be addressed to K.C. (email: kcomer@rice.edu)
} 


\section{Introduction}

$\mathrm{n}$ the fight against the Global Right, an unlikely political force - surfeminism-is emerging across many of the world's coastal places. Surfeminism is a network connecting people, ideas, particular coastal geographies, online and real time communities, and the microeconomies of the multibillion-dollar global surf industry (think of giants like Billabong, Quiksilver, Roxy, Reef). Through action campaigns, artistic ventures, and innovative organizations, activist women and girls who surf are banding together to organize in favor of a range of feminist issues. A rallying point most of the world over is protest of the objectification of female surfers in subcultural media and the demand for media to publicize visuals of women surfing (not modeling) widely available in feminist photography, film, video, and art. Interventions upon heterosexist media representation go in hand with broader political analyses and action platforms. Surfeminism focuses on access of women and girls to public ocean and beach spaces, environmental and ocean health, as well as issues of racial and economic justice, and physical liberation across the lifecycle. One of the most complex demands of surfeminism is for leisure as a political need.

As a concept, surfeminism characterizes a structural location of women and girls in relation not only to issues of gender and sexuality, but to global media, social hierarchies, coastal development and ocean climate (Comer, 2010a). Recognition of shared structural locations allows scholars and activists alike to take a larger view of surfing itself as a fruitful site for feminist analyses of material geographies, contemporary global economies, colonial and settler colonial histories, race and indigeneity, national geopolitics, and the politics of mobility, leisure, and cultural practices. As do other new feminisms opposing the Global Right, surfeminists mass mobilize, demand accountability, participate in campaigns like \#MeToo, \#BILDSexism, No More Page 3, and the Global Women's Marches. Two surfeminists from California (Cori Schumacher and Dionne Ybarra) ran for public office in the 2016 US midterm elections. What is important and unique is that surfeminism is traveling across world spaces by working between publics of academia and global surfing and by forging alliance between women who surf and their allies. One site of this work between publics is the Institute for Women Surfers (IWS), a public humanities project in grassroots political education. In this moment of political urgency, the international forum Signs: A Journal of Women \& Culture has urged feminist scholars to bridge academic and larger feminist publics and attend to creative new movements. Surfeminism and the IWS are instances of bridging.

What is at stake? Surfeminism has shown up on the world stage in the same period that has witnessed the arrival of misogynist authoritarian regimes in the United States, Brazil, Italy, Poland, Hungary, and the Philippines (Beinart, 2019). Stories of women who tell tales about sexual predators often turn out to be similar, and painfully, so are details of these arrivals. Brazil's Bolsonaro \& Trump governing by tweets, plundering environment (Brum, 2019). All of them boasting of personal assault exploits or sanctioning state violence in wars against women. What authoritarianisms of recent global vintage share are strategies of political consent generated less through appeals to racism or class resentment than to male domination, humiliation of women leaders, and curtailments of women's rights and power. Well before the 2016 Trump election and authoritarianism's global ascent, eminent feminist scholars like Angela McRobbie warned about the dangers of "a re-patriarchalization" of Western gender orders (McRobbie, 2008). Indeed, for most of the 21st century, feminist thinkers including surfeminists fought the wholesale appropriation of the ideals of feminism and girl power as they were put in service of new neoliberal market economies. These repurposing moves are characterized in feminist studies by the term 'postfeminism' - the idea that feminism is dated, the Western world is 'post'-feminist because sexism has been defeated, and confidence or self-care are women's big problems today. Postfeminism amounted to a massive antifeminist ideological offensive, confusing public discourse and delegitimizing feminist campaigns including for reproductive justice. In retrospect, perhaps it is less shocking that, in the dumbed down postfeminist public sphere of 2016, Trumpism capitalized on repatriarchalized publics while fueling new ones.

In this period of intensification of work in late capitalist economies and of paid labor as world marker for women's equality across national contexts, a distinct feature of surfeminism is its understanding of leisure as a political need. By definition, it insists on women and girls as worthy of leisure. The category of women's work consists of the "double day," the unpaid labor of caring or social reproduction (care economics of childrearing, elder care, social care broadly) as well as other subsistence or paid labor (Folbre, 2002). "What leisure?" many of the world's women might ask. Surfing at root is about fun and pleasure, it requires time. It also requires access, know-how, social permission, all of which are at issue disproportionately for women and girls. The project of opposing structured limits and creating "culture change" (as many organizations call the task) is part of the explicitly feminist dimensions of surf activisms.

\section{Surfeminist publics}

The IWS fuses university and non-university knowledges in the service of local and global feminist social change (www. insituteforwomensurfers.org). Co-founded in 2014 through a collaboration of the scholar Krista Comer and the activist and world champion surfer Cori Schumacher, the IWS is a grassroots political education project in the public humanities headquartered at Rice University in Houston, TX, USA. IWS defines its public humanities spaces as peer environments in which expertise moves between activists, family and youth workers, non-profits, artists, and researchers (from undergrads through professors) in educational institutions. The Institute was founded after activist surfers contacted Comer, reporting they had read her Surfer Girls in the New World Order, and found versions in it of themselves and the "big picture" of women's subcultural situation (Comer, 2010b). Combining oral histories, ethnography sited in California, Mexico, South Africa, and analyses of Indonesia, with feminist theories of globalization and concepts of critical geography, Comer argued that practices of surfing in male dominated natural spaces had politicized women and girls in both feminist and environmentalist directions. Though indeed surfers were made confident or empowered by surfing, they were not depoliticized poster girls for a postfeminist "New World Order." The archive Comer amassed showed the feminism of women's professional surf organizations of the 1960s-1980s, women's filmmaking and photography since the 1990s, and on-the-ground international female-focused surf camps and surf businesses which interwove with activisms by legends like Rell Sunn, "Queen of Makaha."

Hoping to align with activist worlds represented in Surfer Girls and make common cause with efforts they had already underway, a project between scholars and activists began to take shape. Initial political goals had to do with racial diversity, transnational projects linking women of color including Muslim women, and a campaign to stop the brand Roxy from heterosexist media exploitation of women surfers. Farhana Huq hoped to increase numbers of women of color in her surf break at San Francisco's Ocean Beach. As a Muslim-American of South Asian descent, she envisioned an online platform-imaginatively named Brown Girl Surf-that introduced women of color surfers to one another and 
expanded their collective power and sense of community. Huq was doing outreach as well to women surfers in India and Bangladesh. Like Huq, Schumacher was a seasoned activist. Well known in the world of surfing as a competitor and incisive political thinker, Schumacher was founding the Inspire Initiative, a non-profit organization dedicated to education, activism, and the participation of diverse women in surfing. She had just launched what became a very successful drive for Roxy to "Stop Your All Sex No Surf" ads (https://www.change.org/p/roxy-stopyour-all-sex-no-surf-ads).

The term "surfeminism" spontaneously erupted from Institute group discussion originating in the first pilot meeting in 2014indexing, at that pre-Trump moment, a sense of political opening and group momentum in spite of a depoliticized postfeminist climate. Schumacher blogged about surfeminism as a visceral body knowledge and situated its politics in relation to notions of intersectional feminisms (Schumacher, 2014). The big wave surfer Bianca Valenti used the Institute's feminist community to raise unequal pay issues in competitive surfing-paving the way for the Committee for Equity in Women's Surfing (www.cews.org), and the major victory of equal pay by 2019 in World Surf League pro surfing. Surfing as a practice of freedom and carefree leisure has become a kind of gospel, an ideology about surfing as a social good widely assumed, as Comer argues in Surfer Girls, to be a vote of confidence in globalization as a world system. Surfeminism thus names a thinking project in which feminism is a theory of power relating to women, girls, heteronormative sexuality, and sport, as well as indispensable in critical analyses of global political economies and surfing's dominant political ideals of freedom. To be sure, surfeminism has never been a vision of gathering all the female-advocacy initiatives in the world of surfing under the banner of a Western-style feminism. All IWS projects have aspired to take the lead of women of color and Global South inspired feminist philosophies and put issues of racial or decolonial and queer justice at the center.

To date, the Institute for Women Surfers has conducted five trainings or group meetings. Three have taken place in California, the last hosted by Stanford University (Comer, 2017a), one in Wales (the Institute Europe, co-founded in 2018), one in Australia (the Institute Oceania, co-founded in 2019). Over a three-day weekend of discussion, communal surfing, and presentations, trainings bring together activists, artists, filmmakers, scientists, educators, and organization leaders. The goal is mutual sharing and learning. The program is free, open by application to the public. It features a public-facing curriculum of excerpted readings available online and designed around that year's theme. The curriculum balances accessibility to multiple audiences with sophisticated conceptual offerings. Balance, for instance, has meant pairing: Huq's activist films Surfing Possibility with Abu-Ludhod's Do Muslim Women Really Need Saving? (2002); "Settler Colonialism 101" with Evers' Notes for a Young Surfer (2010); Kelly's Freedom Dreams alongside songs of Missy Elliott; poet Holly McNish with Ahmed's Living a Feminist Life (2017); YouTubes in feminist visuality by Peter Berger with Guerrilla Girls and Pepin Silva's One Winter Story (2006) and Introducing the Super Stoked Surf Mamas of Pleasure Point (2018). Invited speakers in longer presentations as well as the briefer participant "skill shares" about projects in process make up the knowledges shared over the weekend. These knowledges are explicitly understood to belong to all who are there even as practices of citation and noting credit are expected. Participating scholars must bracket academic language and engage in public-facing pedagogies.

\section{Surfeminist knowledges}

Obviously, there is no single answer to research and political questions that span world geographies. But knowledges that shed feminist light are being produced through the IWS and intermixed with fields of Sports for Development and Peace (SDP), sports sociology, and the interdisciplinary field of Critical Surf Studies. Comer's "ethnographies from below," in Surfer Girls, which has informed IWS curricula, for instance, drew from SDP cautions about pro-corporate relations between development projects and sports to embrace decolonial methods of equitable power sharing (Darnell and Hayhurst, 2011), and postcolonial feminist cross-border alliances (Hayhurst, 2016). The library of writings in sociology of sport and human movement by scholars Belinda Wheaton, Holly Thorpe, Rebecca Olive, and lisahunter, have addressed identity and power in organized versus lifestyle sports, sports and development for girls in contexts of war and disaster, blogging as feminist community building, visions of sport de-gendering, issues of pay equity in Olympic sports, and women and eco-activism.

The burgeoning field of Surf Studies, related to but distinct from the above, has built itself through interdisciplinary analyses of power and politics, and current bibliographies for surfing scholarship run long, deep, and international. A wonderfully curated essay collection, the Critical Surf Studies Reader, frames surf studies through intersections of Modern Surfing States, colonial histories and indigenous revitalizations, issues of racialization, consumer capitalism and feminist political economy (Hough-Snee and Eastman, 2017). The Reader indexes an important moment of maturation in this young field as contributors foreground, as do surfeminists, the stakes of research straddling the publics of academia, profit-driven surf industry, and diverse surf communities worldwide. One of the collection's sections, "Feminist Critical Geography" features Comer's comments on surfeminism, concepts of critical regionalism, and public scholarship (Comer, 2017b); lisahunter's thoughts about the centrality of sex to surf studies pedagogies (lisahunter, 2017); and Schumacher's arguments, through a study of the mermaid figure, for surfeminism as an embodied queered surf subjectivity tied to new materialist environmental politics and ontology (Schumacher, 2017). One of the trickiest topics the volume raises concerns the politics of mobility and travel as they are revealed in tourism since strategies of "ethical capitalism," ecotravel, and research interests entangle in one another for very vexed social and climate justice reasons.

A crucial point about overlapping knowledges is that it is not "only" scholarship of scholar A or B that matters in producing surfeminist theory. Scholars' participation in the Institute for Women Surfers, and in real time actions (film screenings, art exhibitions, organization surf days, clean ups, activist talks), also matters. Participation contributes to surfeminism as a publicfacing knowledge that closes gaps between universities and activist expertise. Direct participants of educators in the Institute alone constitutes a long international and cross-disciplinary list: Mercedes Albert, Laura Alfrey, Martina Burtscher, Margaret Cohen, Cassie Comley, Sachi Cunningham, elke emerald, Dina Gilio-Whitaker, Tala Khanmalek, Barb Humberstone, lisahunter, Michelle Habell-Pallán, Alison Rose Jefferson, Emily Marsay, Rebecca Olive, Tara Ruttenburg, Margaret Seelie, Lyndsey Stoodley, Carly Thomsen, Laura Truelove, Annie Yaniga, Kirsten Yonan. Add to it those who have indirectly participated, written FaceBook postings, sent new contacts, including many male allies. Institutions of higher education rarely reward public-oriented work or outcomes that are non-publications. Public humanities projects thus are difficult. But so vital-they respond to communities, are not as governed by academic protocols, and can move quickly to respond to the urgencies of the present.

The election of Donald Trump sent shockwaves across the worlds of surfeminism. From the start, the Institute for Women Surfers was constituted through a core group of California activist 
surfers, educators, and artists-Mira Manickam-Shirley, Dionne Ybarra, Elizabeth Pepin Silva, Dina Gilio-Whitaker, Dayla Soul, and Bianca Valenti. Since 2016, the work of all of them has been retooled. Brown Girl Surf, under the leadership of Mira Manickam-Shirley since 2016, declared "Civics is Sexy!" As a culture change movement blending surfeminist hip hop with urban environmental justice advocacy and embedded in Oakland, Brown Girl Surf has been a model for building surf movements over well-meaning "charity for a day" outreach programs. In the new political moment, however, Brown Girl Surf, in partnership with Jennifer Savage of Surfrider Foundation, took its political game in new directions. Brown Girl Surfers are no strangers to street protest - the Black Lives Matter movement was partly born in Oakland (Torrez, 2018) and anti-racist organizations like Brown Girl Surf make common cause with \#BLM constituencies. But the new moment of Trump has also meant organizing community events to skill-build a more active citizenry, including learning to craft public testimony, speak at public hearings, and command the attention of California lawmakers.

The theme of "access" of the 2017 Institute threaded through a number of projects, as well as showed dividing lines of politics that work through racial justice rather than sovereignty priorities. "Access" suggests governmental initiatives as in policies for access to beach spaces or public systems like transportation. Access also suggests belonging or exclusions in realms of imagination and art, "intangible barriers" to coastal spaces. Access does little to recognize indigenous sovereignty. The writings and interactive Institute workshops of Dina Gilio-Whitaker (Colville Confederated Tribes) has transformed the work of the Institute and demonstrated the degree to which settler colonialism frames surf culture in its entitlements to local places (Gilio-Whitaker, 2015). Surfeminism has been altered by recognitions that anywhere IWS meets in the US, or surfers surf, will always be a meeting or a surf in Indian Country. This language of decolonizing surfing has been structured into Institute objectives as a political aspiration.

Following up the 2017 Institute theme of access in the new moment of surfeminism in the era of Trump, alliances between activists negotiated California and federal law related to access, meaning the not-theoretical divide between racial and indigenous justice priorities. Collaborative presentations related to environmental and feminist justice were invited from the Green California Summit, and Restore America's Estuaries, and brought to the table Institute participants from Brown Girl Surf, Project Wahine/El Proyecto Wahine, City Surf Project, and Surfrider. At the time of the Summit panel, Assembly Bill 1782 proposed that surfing be named the official state sport of California. The bill's version of state history did not acknowledge the ancestral homelands of some forty coastal Native nations. With GilioWhitaker's leadership and input from activist lawyer Angela Mooney D'arcy of Sacred Spaces, a partnership between representatives from the IWS and again Jennifer Savage of Surfrider met with Congressional staffers in Sacramento to alter the bill's language. The final bill reflected a more indigenous-conscious history. Known surf commentators, like Sam George, chided the change as nonsensical (George, 2018). Activist alliances held across racial environmental justice needs and preservation of indigenous histories. In effect, the Surf Bill is the first indigenous land acknowledgement in the state of California, offering a small step toward decolonial unerasings of settler history and indigenous visions of environmental justice (Gilio-Whitaker, 2019).

Questions of access also underwrote the right of women to compete at the legendary Mavericks, fought and won by Bianca Valenti and the Committee for Equity in Women's Surfing. The battle was an equal rights battle on known feminist terms. But the intensity of masculine hostility is made more intelligible through theories of settler coloniality supercharged by authoritarian misogyny. Mavericks was a battle for settler masculine rights, the privilege of settler surfers to be "native" in a local place. Local big wave hero, Jeff Clark, "discovered" an unknown giant wave, for years he surfed it alone before sharing it with an elite coterie of buddies. Captured memorably on film by Dayla Soul in It Ain't Pretty (2016), Clark and others believed they owned Mavericks and were entitled to control who competed there. Until a group of feminist activists, including elected officials and attorneys, brought the deep state, meaning the influential California Coastal Commission, to bear on surf industry's World Surf League, which oversees the contest. The issue of inclusion and pay equity was forced. The story of this political battle was recently reported in the New York Times (Duane, 2019). Surfeminism in an era of Trump would offer a settler analysis and point to the intense Trumpism fueling the backlash and posted on Facebook pages by some of Jeff Clark's most avid supporters.

\section{IWS in Wales \& Oceania}

Expansions of the Institute in international directions have grown from commitments to the importance of geography and place, and make ever more sense in current political climates. There should be no one-size-fits-all universal surfeminism. Local laws and social conventions exist in relation to national policy and governmental norms. On-the-ground activist campaigns and situated social worlds are the seedbeds of relevant theory and practice. Feminists acting in concert with one another against authoritarianism are well positioned to act as watchdogs and advise one another, as the scholar of gender and militarism, Cynthia Enloe, puts it, country by country, xenophobia by xenophobia (Enloe, 2018). While California trainings hosted participants and projects from Costa Rica, England, Ireland, and Spain, recent Institutes have been cofounded in Europe and Oceania. The launch of IWS Europe around the theme "Collaboration," and IWS Oceania around "Visibility, Respect, and Action," identify feminist goals significant to these surf communities.

IWS Europe, co-founded Lyndsey Stoodley, brought women together in Cardiff, Wales, from England, Scotland, Austria, Australia, and the United States. Held immediately in advance of Trump's anticipated visit to the Queen, the IWS training was itself targeted by Welsh Surfing Association members on social media as full of "ugly" and "old" women. Outspoken feminists like co-founder Dani Robertson, of Surf Senioritas (Robertson, 2015), and champion English surfer Sophie Hellyer, have been frequent targets of attacks. Organized networks of surfeminists fighting violence against women made use of Institute community to devise safehouses for women who surf in need of quick escape. Days after the meeting, women and especially mothers with children took to the streets throughout the UK, protesting family separation policies, withdrawal from the Paris Climate agreement, and delighting in the Baby Trump blimp flying over English cities. In the immediate aftermath of the Wales IWS event, surfeminists talking over group text sent one another photographs of protests in respective home places.

The decolonial philosophies of The Institute Oceania, launched in 2019, and co-founded by Dr. lisahunter of Monash University Peninsula Campus, is bringing new collaborators and interests to an expanding menu of concerns. Women from Australia, Vanuatu, Aotearoa/New Zealand, as well as Wales, England, the USA, and Brazil, used master classes by filmmaker Elizabeth Pepin Silva to think toward arts and environment. Colleagues who farm coral from Solwata Sista, an organization located in one of the smaller Pacific Island nations of Vanuatu, proposed new alliances for skill-sharing about larger scale coral restoration. They requested and received promises of equipment sharing. 
Surfing Mums, an organization with many chapters in Australia, learned about organized groups of mothers who surf in the US through Pepin Silva's film Introducing the Super Stoked Surf Mamas. Paula Tura's film Gaia's Daughters (2019) about surfing and motherhood, sited mainly in Australia though Tura is a Brazilian, like other surf mothering films, uses surfing as a way to talk about maternal mental and physical health, shared labor. They highlight the crises of social reproduction feminists see as hallmarks of neoliberalism (Arruzza et al., 2019). Tura has no idea what to expect when she shows the film in Brazil this summer. She reports extremely bad political climates for women under Bolsonaro, the "Trump of the Tropics," and friends/activists share horror stories about the new antifeminist climate on closed Facebook pages. But she wants to go home, surf, see what kinds of surfeminisms she can create.

\section{Call to feminist public humanities}

At present, surfeminism is expanding audiences and political strength. A sense of optimism and international cooperation and solidarity is growing from new relationships and sharpening analyses. Because of its novel structural locations in coastal developing nations and the marginality of women across surf cultures historically, surfeminism as a politics often can see from outside perspectives what other analyses miss. It may also fly under the radar of policing. To the unaware, it might look like "just a bunch of girls in bikinis." The case of the fight for Mavericks is one instance where surfeminism did appear front and center, and met a full throttle settler authoritarian response. And won.

As suggested earlier, surf industry promotes its world image through notions of girl-friendliness and outreach programs that tout and accomplish to differing degrees the building of female confidence and capacity. Neoliberalized forms of feminism, of which many local women's empowerment initiatives are examples, may be in fact the dominant form of project on the world market. Clearly, however postfeminist celebrations of individual choices and style options ("marketplace feminisms") or body-positivity programs (personal "empowerment feminisms") are insufficient to the demands of the present (Zeisler, 2016; Banet-Weiser, 2018). No amount of surfing as leisure practice on its own will stem warming waters, intimate violence, or authoritarian misogynies.

But by and large, depoliticized postfeminist practices of selfcare associated with "women's leisure" are not the political need for leisure that surfeminism demands. It demands clean water for its leisure, healthy coral beds, maternity done in contexts of community and not overwork. It wants a diversity of women in the water. It commits itself, as is standard language in activist Australia, to reconciliation processes that include respect, recognition, learning and indigenous self-determination. All of this work demands respect for and intelligence about relationships and alliance building. The charge here is to work between publics, build alliances, of scholars with activists, and activists with scholars. Laura Briggs sums up keys to solidarity: activists must trust educators, not overestimate their institutional resources, be open to conceptual thought and what it offers. Scholars must appreciate the intellectual work of activists, and the nuts and bolts work activists do (Briggs, 2008). It turns out that the political need of leisure is a lot of work. What may be most important to present fights against the Global Right is the ability of feminist relationships to survive the inevitable strains of coalitional politics. In surfeminism, there is sure to be some stoke along the way to making better worlds.

Received: 26 January 2019 Accepted: 26 March 2019

Published online: 30 April 2019

\section{References}

Arruzza C, Tithi B, Nancy F (2019). Feminism for the 99\%: a manifesto. Verso Press, London

Banet-Weiser S (2018) Empowered: popular feminism and popular misogyny. Duke University Press, Durham

Beinart P (2019) The new authoritarians are waging war on women. The Atlantic online publication January 8 , https://www.theatlantic.com/magazine/archive/ 2019/01/authoritarian-sexism-trump-duterte/576382/

Briggs L (2008) Activisms and epistemologies: problems for transnationalisms Soc Text 97 26(4):79-95

Brum E (2019) Bolsonaro (des) governs Brazil through Twitter. El Pais. https:// translate.google.com/translate $\mathrm{hl}=\mathrm{en} \& \mathrm{sl}=\mathrm{pt} \& \mathrm{u}=\mathrm{https} / / / \mathrm{brasil} . e l p a i s . c o m /$ brasil/2019/03/06/opinion/1551904505_351681.html\&prev=search

Comer K (2010a) Krista Comer and the culture of surfing. https://www.youtube. $\mathrm{com} /$ watch? $\mathrm{v}=\mathrm{ax} 04 \mathrm{ICMHgv0}$

Comer K (2010b) Surfer girls in the new world order. Duke University Press, Durham

Comer K (2014) About IWS. Institute for Women Surfers Website. https://www. instituteforwomensurfers.org. Accessed 15 Jan 2019

Comer K (2017a) Beaches as spaces of democracy: center hosts women surfers conference. Stanford University Bill Lane Center for the American West Blog. https://west.stanford.edu/news/beaches-spaces-democracy-center-hostswomen-surfers-conference. Accessed 3 Jan 2019

Comer K (2017b) Surfeminism, critical regionalism, and public scholarship. In: Hough-Snee DZ, Eastman AS (eds.) Critical surf studies reader. Duke University Press, Durham, p 235-62

Darnell S, Hayhurst LMC (2011) Sport for decolonization: exploring a new praxis for sport and development. Prog Dev Stud 11(3):183-96

Duane D (2019). The fight for gender equality in one of the most dangerous sports on earth. New York Times, February 7. https://www.nytimes.com/interactive/ 2019/02/07/magazine/women-surf-big-wave.html. Accessed 1 Mar 2019

Enloe C (2018) Ask a feminist: Cynthia Enloe discusses gender and the rise of the global right with Agnieszka Graff, Ratna Kapur, and Suzanna Danuta Walters. podcast, http://signsjournal.org/cynthia-enloe/

Folbre N (2002) The invisible heart: economics and family values. Free Press, New York, NY

George S (2018) It's official: surfing is now California's state sport. Surfline. https:// www.surfline.com/surf-news/official-surfing-now-californias-state-sport/ 32735. Accessed 20 Jan 2019

Gilio-Whitaker D (2015) Surfing and Indigeneity in the United States. https:// dinagwhitaker.wordpress.com/2015/11/10/surfing-and-indigeneity-in-theunited-states/. Accessed 10 Apr 2019

Gilio-Whitaker D (2019) As long as grass grows: the indigenous fight for environmental justice from colonization to standing rock. Beacon Press, Boston

Hayhurst LMC (2016) Sport for development and peace: a call for transnational, multi-sited, postcolonial feminist research. Qual Res Sport Exerc Health 8 (5):424-443

Hough-Snee DZ, Eastman AS eds. (2017) The critical surf studies. Duke University Press, Durham

lisahunter (2017) De-sexing surfing? Pedagogies of possibility. In: Hough-Snee DZ, Eastman AS (eds.) Critical surf studies reader. Duke University Press, Durham, p 263-83

McRobbie A (2008) The aftermath of feminism: gender, culture and social change. Sage Publications, Thousand Oaks

Robertson D (2015) Surf senioritas. https://www.facebook.com/groups/surfsenioritas/. Accessed 5 Jan 2019

Schumacher C (2017) 'My Mother is a Fish': from stealth feminism to surfeminism. In: Hough-Snee DZ, Eastman AS (eds.) Critical surf studies reader. Duke University Press, Durham, p 284-302

Schumacher C (2014) Thoughts on a surfeminism. Cori Schumacher: State of Flux. https://www.corischumacher.com/2014/07/23/thoughts-surfeminism/. Accessed 15 Jan 2019

Torrez A (2018). Five years of Black Lives Matter. http://www.ktvu.com/news/5years-of-black-lives-matter-a-movement-led-by-women-partly-born-out-ofoakland. Accessed 9 Apr 2019

Zeisler A (2016) We were feminists once: from riot grrrl to CoverGirl ${ }^{\circledR}$, the buying and selling of a political movement. Public Affairs, New York, NY

\section{Additional information}

Competing interests: The author declares no competing interests.

Reprints and permission information is available online at http://www.nature.com/ reprints

Publisher's note: Springer Nature remains neutral with regard to jurisdictional claims in published maps and institutional affiliations. 
(c) (i) Open Access This article is licensed under a Creative Commons Attribution 4.0 International License, which permits use, sharing, adaptation, distribution and reproduction in any medium or format, as long as you give appropriate credit to the original author(s) and the source, provide a link to the Creative Commons license, and indicate if changes were made. The images or other third party material in this article are included in the article's Creative Commons license, unless indicated otherwise in a credit line to the material. If material is not included in the article's Creative Commons license and your intended use is not permitted by statutory regulation or exceeds the permitted use, you will need to obtain permission directly from the copyright holder. To view a copy of this license, visit http://creativecommons.org/ licenses/by/4.0/.

(C) The Author(s) 2019 